\title{
TALENT MANAGEMENT AND ITS ROLE ON SUPPORTING THE COMPETITIVENESS IN THE AIRLINE COMPANIES
}

\section{By \\ Reham Mamdouh Mohamed Abd El-Maksoud}

Assistant Lecturer in Tourism Studies Department

Faculty of Tourism and Hotels Mansoura University

\section{Prof Dr. walid Sayed Amin}

Professor in Tourism Studies Department

Faculty of Tourism and Hotels

Mansoura University

\section{Prof Dr. Doaa Samir Hizah}

Professor in Tourism Studies Department

Faculty of Tourism and Hotels Mansoura University

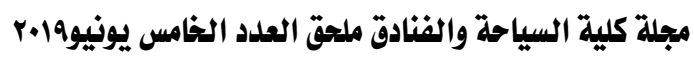

الخاص بالمؤتتمر العلمي الدولي الثاني - التسويق السياحي لمنطقة الدلتانت 
Talent Management and its Role on Supporting the

- Competitiveness in the Airline Companies

\title{
TALENT MANAGEMENT AND ITS ROLE ON SUPPORTING THE COMPETITIVENESS IN THE AIRLINE COMPANIES
}

\author{
Reham Mamdouh \\ Mohamed ${ }^{3}$ \\ Prof Dr. Doaa Samir \\ $\mathrm{Hizah}^{2}$ \\ Prof Dr. walid Sayed \\ $A_{\min }{ }^{1}$
}

Era of globalization requires companies to attract human capital and retain them for the very best output so that the employees can compete internationally. The organization's efforts to recruit, develop and maintain talent, directly linked to their success in the business environment.

So we can define Talent Management as an array of practices used to manage people effectively at work. It tends to be seen as an integrated set of activities, mostly concentrated on developing people to meet changing business needs.

The core problem of this paper is that many airline companies do not care about talent management, as well as the lack of strategies to deal with talented people in the airline companies. Therefore, there is an urgent need to allocate human talent management and activate its role to contribute to the success of airline companies as they are considered an intellectual capital of the organizations.

The Study aims at: 1- Highlighting the importance and components of administrative human talent, the reasons for naming it a talent and how to deal with talented within the administrative organization. 2- Clarifying the most prominent strategies for the application of talent management practically. 3Highlighting the challenges facing talent management in the airline companies. 4- Putting a general framework represents a proposed model of the impact of talent management system on the airline companies' performance. 
The study based on two hypotheses; the first hypothesis based on the lack of strategies of Talent Management in the airline companies, and the second hypothesis based on the existence of a statistically significant relationship between Talent Management and supporting competitiveness in the airline companies.

The study was applied on the Egyptian airline companies. The methodology of the research is based on the descriptive method and the field method. The questionnaire is the main tool for collecting data for the field study; the responses were analyzed to come out with some results that have contributed to the statement of recommendations made by the study.

Keywords: Talent Management, competitive advantages of airline companies.

\section{Introduction}

Privilege and success have become the main target of modern organizations so that they can continue, grow and progress and have the ability to compete in the changing and evolving global economic system. Investing in human resources is the main entrance to increase the competitiveness of different organizations (Radwan, 2012).

Studies have shown that when organizations invest on talents, the revenues will be significant increased. Financial value of the organization depends on the quality of their talents, and talents quickly increase the financial value of the organization. As a result, talents can have a positive impact on the performance and success of the organization (Vaseghi and Moayedi, 2016).

\section{Problem of the Research}

The core problem of this research is that many airline companies do not care about talent management, as well as the lack of strategies to deal with talented people in the airline companies. Therefore, there is an urgent need to allocate human talent management and activate its role to contribute to the success of 
airline companies as they are considered an intellectual capital of the organization.

As well as talent management is the key to how to transform the threats resulting from the prevailing changes in administrative and economic systems and the limited resources of companies to real opportunities that can be used to achieve competitive advantage and achieve growth, development and sustainability. The real competitive advantage is not only in information systems, work structures, equipment or devices but also in staff and success in talent management .

\section{Importance of the Research}

The importance of the study comes from highlighting the concept of talent management, which is not clarified as required, making it difficult to achieve the usefulness of its application practically. As well as providing recommendations to airline officials on how to invest in talent management and its role in enhancing the competitiveness of airlines. The importance of the study is also a result of lack of Arabic literature and research in this field.

\section{Objectives of the Research}

The Study aims at: 1- Highlighting the importance and components of administrative human talent, the reasons for naming it a talent and how to deal with talented within the administrative organization. 2- Clarifying the most prominent strategies for the application of talent management practically. 3Highlighting the challenges facing talent management in the airline companies. 4- Putting a general framework represents a proposed model of the impact of the talent management system on the airline companies' performance.

\section{Hypotheses of the Research}

The study based on two hypotheses; the first hypothesis based on the lack of strategies of Talent Management in the airline companies, and the second hypothesis based on existence of a 
statistically significant relationship between Talent Management and supporting competitiveness in the airline companies.

\section{Methodology of the Research}

The methodology of the research is based on the descriptive method and the field method. The questionnaire is the main tool for collecting data for the field study; the responses are analyzed to come out with some results that have contributed to the statement of recommendations made by the study.

\section{1- What is Talent?}

Human talent is not an abstraction; by investing properly, companies obtain real value from building better talent, that involves making a series of choices for all of four stakeholder groups - customers, investors, employees, and executives (Ulrich\& Smallwood, 2012).

Definitions of talent can vary; some define talent as a high performance and potential of a selected number of employees to move up the organisation into top leadership or managerial positions. While others consider talent as an inclusive term that refers to all employees (Fitzgerald, 2014).

Some defined talent as "An individual's skills and abilities (talents) and what the person is capable of doing or contributing to the organization." (Gallardo, et al., 2013)

Talent is a combination of; demonstrated capability (present and past performance), implied or future capability (prediction of future complexity), motivation and self-development (willingness to learn, to look for challenges, etc) and Career development and growth (O'Callaghan, 2008).

\section{2- Human Talent Management}

Talent Management as a research area has only attracted attention in recent years. It is unclear in its definition and in an early stage, both as a managerial practice and especially as a field of academic research (Börjesson and Tyskbo, 2015). 
In 1997 McKinsey \& Co started a research which pointed out that the war on talent was the main area where many organizations were fighting to obtain or maintain a competitive advantage (Merlevade, 2014).

Talent Management is a multi-faceted concept that has been championed by HR professionals, supported by the war for talent and built on the foundations of strategic HRM. It may be seen as an organizational culture or mindest in which employees are really valued; a source of competitive advantage; an effectively integrated and enterprise-wide set of sophisticated, technology enabled; and an evidence-based HRM policies and practices (Hughes and Rog, 2008).

So we can define Talent Management as an array of practices used to manage people effectively at work. It tends to be seen as an integrated set of activities, mostly concentrated on developing people to meet changing business needs (Campbell and Hirsh, 2013).

\section{2-1 Talent Management Challenges}

Organisations today face formidable talent challenges. The ability to sustain a steady supply of critical talent is a challenge facing all companies - worldwide (Hewitt Associates and Human Capital Institute, 2008).

Companies face the absence of a clear plan and strategy to develop skills and capability at all levels for all employees. Employees have no guideline for acquiring the skills they need, organizations have not identified the need for future success and skills development often becomes an operational necessity, as opposed to a long-term strategic business. In addition to the fine line between developing talent and potential, and the risk of making staff more employable; The more investment in people, the more attractive they become to competitors and the market (O'Callaghan, 2008). 


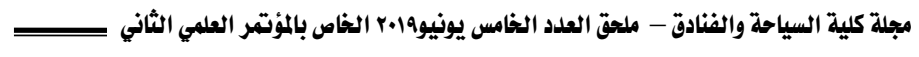

Innovative ideas, strong execution, and a foundation of clear metrics can allow many more talent management professionals to create a talent mindset that will prepare their companies to face the challenges ahead (Hewitt Associates and Human Capital Institute, 2008).

It is also important when managing talent, providing staff with appropriate opportunities to practice new skills and competencies. Companies often invest fortunes to develop talented people and then they go back to their old role with the old routine with no opportunity to execute new skills and knowledge (O'Callaghan, 2008).

\section{2-2 Talent Management Framework}

The successful implementation of three major factors listed below is mainly for managing talented staff in organizations:

- searching for and engaging talents by using quality personnel assessment methods pointed at identifying talents at the hiring stage or by using internal sources to attract them ("bringing up talents" from available staff members);

- shaping and enhancing major professional and managerial competencies among talented staff members with a view to improve the level of their personnel potential and the company's human capacity altogether;

- retaining talented employees through motivating them as well enhancing their loyalty to the organization (Danilina, E, I., et al., 2017).

The components of the talent management system are the integrated system using the process of talent management incl uding eight elements:

\section{2-2-1Talent Identification}

Talent identification is the first step in any strategic Talent Management System that helps to find qualified talent to be the organizational talent model for essential positions that affect the organizational success.Talent identification is the searching and 
determining of the talent characteristics that organisations can identify the talent characteristics model from the old talent employee and/ or form new talent characteristics model (Tepayakul and Rinthaisong, 2016).

\section{2-2-2Talent Recruitment}

The following factors are considered essential to recruitment: competitive base pay, work/life balance, challenging work, career advancement opportunities, salary increase connected to the individual performance, competitive benefits, learning and development opportunities, competitive retirement benefits, and the reputation of the organization as a good company (Egerova, et al., 2013).

\section{2-2-3 Talent Selection}

Traditional employing practices such as conducting interviews, examining resumes, checking references are becoming out of date. It is becoming more common to include an objective measure of performance, as psychological assessment, in combination with other recruitment tools in order to enhance a company's chances of matching the right person to the job. Personality assessments, behavioral interviews, and job knowledge tests can serve as valuable selection, employment and promotion tools (Phillips and Roper, 2009).

\section{2-2-4Talent Development}

Development through various consultations for staff of different levels of the organisation in order to recognize strengths and weaknesses and their actual and potential talent; in-service training courses inside and outside of the organisation for staff of different levels of the organisation; create the research and development teams and the development of staff skills and experience-related tasks (Shafieian, 2014).

\section{2-2-5 Talent Retention}

The next expected question is, "Now that we've trained them, how do we keep them?" Employee retention is closely linked to 
an organisation's performance management system. The most significant factors driving employee retention are opportunities to develop and advance in their careers. One of the best predictors of turnover is whether an employee had recently received training. Executives who feel they have been made to wait longer for promotions are more likely to become dissatisfied and quit. In this case, success can rely on having a succession planning process focused on long-term organizational implications and sharing that with staff (Phillips and Roper, 2009).

\section{2-2-6 Talent Compensation Management}

Compensation package should clearly articulate skill requirements, expectations of performance, experience, and behaviour. This system should be developed to drive top performance at every skill level within the company. Compensation and benefits should boost the organisation's overall goals, not just in recruiting and retention, but as well in business performance, commonly referred to as the HR Scorecard, in which employees and strategy are linked with performance (Phillips and Roper, 2009).

\section{2-2-7 Talent Performance Management}

By using the business plan, the organisation establishes processes to measure and manage staff (Banarjee, 2014).

Organisation should execute a performance management system. Strategic goals must be cascaded top-down, individual crucial performance indicators and a performance evaluation system have to be adjusted for each employee and a sufficient amount of information has to be provided.As well as the performance system has to be connected with the reward system (Egerova, et al., 2013).

\section{2-2-8 Succession Planning}

As the organisation evolves and changes, there is a continuous need to move employees into new positions. Succession planning, 
a very significant function, enables managers and individuals to identify the right candidates for a position (Banarjee, 2014).

Succession Planning was a frequently used term to represent a proactive process of tailoring skill and career development to provide good- calibre employees for future vacant posts (Campbell and Hirsh, 2013).

\section{2-3 Talent Management Importance}

Talent management is important for at least two essential reasons. The first is that effective talent management assures that organizations can successfully acquire and retain essential talent that helps to avoid the dire consequences of having insufficient or inappropriate employees. The second has to do with the extent to which these employees are engaged, talent management is integral to engaging employees in the organization. The ability to effectively manage both of these issues has become an essential determinant of organizational success and in some cases, even survival (Hughes and Rog, 2008).

Effective Talent Management offers very real and tangible benefits which include; reducing recruitment costs, realisation of business strategy, delivery of cutting edge services and products, creating a competitive advantage, reducing risks (one employee in hand is worth 200 in resumes), improving client retention, clients value relationships and talented people often are critical to valuable client relationships.

Organisations should remember that it is easier to keep old clients than to find new ones, as well as the fact that they will not have loyal clients without loyal staff (O'Callaghan, 2008).

\section{3-Differentiating TM and HRM}

Regarding the difference between TM and HRM there are different meanings given in literature. For example, TM is considered as not fundamentally different from HRM as well authors speak from a replacement of HRM with TM. Most authors see TM as a part of HRM or integrated HRM with a 


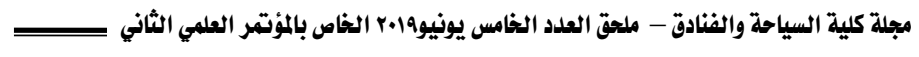

selective focus (Atan \& Stapf, 2017). Human Resources Management has broader scope than Talent Management; TM is considered one of the activities of HRM.

Talent management is the implementation of integrated strategies or systems designed to enhance workplace productivity by developing improved processes for recruiting, developing, retaining and utilizing people with the required skills and talent to meet current and future business needs (Banarjee, 2014). As well as TM is based on workforce differentiation, recognized as the key distinguishing characteristic between TM and HRM (Atan \& Stapf, 2017). One of the optimal activities of TM is to ensure right person in the right place in a right time.

Additionally HRM emphasizes on equalization, while TM emphasizes on segmentation. HRM deals with each employee in a similar way and aims to avoid differentiation in the allocation of company resources, while TM treats specific employees differently, and starts to pay attention to different demands of different groups of employees.TM focuses on people, while HRM focuses on its organizational function as a whole (Banarjee, 2014).

\section{4- Competitiveness of the Airline Companies}

When the developments in the airline sector are examined, it is visible that there are many factors which make it necessary to develop effective competition strategies and execute them( Kilinc, et al., 2012).

With a growth in the demand for air travel globally, competition amongst international airlines is increasing. With these challenges companies need cultures and systems where employees can actually use their talents and management practices can produce extraordinary results from almost everybody. HR practices enhance the company's competitive position by creating outstanding human capital that contributes to company's economic value. Accordingly, the value of human resources in the 
organisation can rise, decline or maintain the same level, depending on how those assets are managed (Roy, 2013).

\section{5- Achieving Competitive Advantage through Talent Management}

An essential task of strategic management is to build and maintain competitive advantages of a business, which should make it possible to accomplish above average outcomes of its business activities (Ceglinski, 2016).

Human Resources can prove that talent management one of strategic importance to organizations, when the critical relationship between the two is proven. Talent management specially needs to be projected as a distinguishing strategic capability that can offer real and essential competitive advantage (Ahmed, 2016).

Competitive advantage is acquired when an organisation develops or obtains a set of attributes (or execution actions) that allow it to outperform its competitors. In other words, competitive advantage is revealed, when activities of a given organisation are more profitable than those of its market competitors or when it surpasses them as regards other significant results of activities (Ceglinski, 2016).

Developing talent and succession planning needs to a deliberate and strategic approach and should be considered whether it fits outside the traditional role of human resources management.

Regarding to sustainable and competitive, the "talent issue" can no longer be ignored (Pollard, 2013).

Managing talent is not easy but necessary to assess the needs and requirements of employment companies that can make progress and success in a competitive market. Talent management is a guarantee for the company to be able to develop its competitive advantage, increase profits, improve production processes and enhance organizational performance (Nazzal, 2016). Talent management theories have been driven by the belief that maximizing the talents of employees is a source of sustained 
competitive advantage. It has resulted in Talent Management becoming extensively linked to Human Resource Management practices in organisations (Vnouckova, et al., 2016).

\section{6-Methodology of the Research}

The study was based on the descriptive method, "Survey Pattern", through the questionnaire, where a questionnaire was prepared and distributed to a random sample of (400) employees in the airlines operating in Egypt during the period from March to May 2019 with confidence period 95\%(Veal, 2016); 300 forms were distributed through field visits, 282 forms were retrieved by $94 \%$ and 181 forms were responded electronically. This sample does not have a statistical reference because of the difficulty of determining the total population of the study. Statistical analysis was carried out through the Statistical Package for Social Sciences program (SPSS). The results of the questionnaire analysis are presented as follows:

\section{6-1-Validity and reliability of the study:}

\section{6-1-1Validity test for the research sample}

For ensuring the validity of the study instrument (questionnaire), the questionnaire was presented to the competent professors to know their opinions on the clarity and consistency of paragraphs of the questionnaire, as well the goodness of questions and compatibility with the subject of the study, where their directions were taken; some paragraphs were added, some were deleted and others were adjusted according to the objectives of the study.

To ensure validity of the research, intrinsic validity was also extracted by calculating the square root of the reliability coefficient, the results were as follows:

Table (1): Validity coefficient of the field study sample

\begin{tabular}{|l|c|}
\hline \multicolumn{1}{|c|}{ Dimensions of the study } & $\begin{array}{l}\text { Validity } \\
\text { Coefficient } *\end{array}$ \\
\hline 1-Awareness of Talent Management. & 0.899 \\
\hline 2-Application of Talent Management. & 0.955 \\
\hline
\end{tabular}


Talent Management and its Role on Supporting the

\begin{tabular}{|l|c|}
\hline $\begin{array}{l}\text { Competitiveness in the Airline Companies } \\
\text { 3-Interest of airlines in measuring their } \\
\text { competitiveness. }\end{array}$ & 0.849 \\
\hline $\begin{array}{l}\text { 4-The impact of Talent Management on the } \\
\text { competitiveness of airlines. }\end{array}$ & 0.930 \\
\hline \multicolumn{2}{|c|}{ Total } \\
\hline
\end{tabular}

* Coefficient of validity $=$ Root of reliability coefficient

It is clear from table (1) that the validity coefficient of the study sample of employees of airlines ranges between (0.849) and (0.955). That indicates to the validity of the study sample which means that each item is genuine under its dimension.

\section{6-1-2Reliability Coefficient}

Table (2):
Reliability Coefficient (Cronbach's Alpha) for dimensions of
the study

Cronbach's alpha is a reliability coefficient that indicates how well the items in a set are positively correlated to one another. It is clear from table (2) that the instrument is characterized by a high reliability coefficient $(0.910)$, which indicates the ability of the instrument in general to achieve the purposes of the study. The table shows that the values of the reliability coefficient range between (0.721) and (0.911). This refers to the stability of the results resulting in the application of the questionnaire, where the values of reliability coefficient (Alpha $\geq 0.60$ ) are suitable for the application of the questionnaire to the study as the closer 


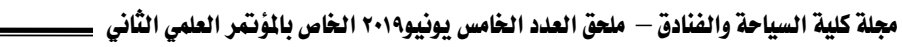

Cronbach's alpha is to 1, the higher the internal consistency reliability (Sekaran and Bougie, 2016).

6-2-General information (characteristics of study sample from airline staff)

6-2-1 experience in air transport and airlines generally:

Table (3): Distribution of employees according to experience in air transport and airlines generally

\begin{tabular}{|c|c|c|c|c|c|}
\hline$\frac{2}{8}$ & $\begin{array}{l}\text { Experience in air } \\
\text { transport generally }\end{array}$ & 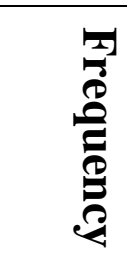 & $\begin{array}{l}\text { Percent } \\
(\%)\end{array}$ & $\stackrel{2}{3}$ & $\begin{array}{l}\text { Standard } \\
\text { Deviation }\end{array}$ \\
\hline 1 & Less than 5 years & 59 & 14.8 & \multirow{5}{*}{3.00} & \multirow{5}{*}{1.119} \\
\hline 2 & 5 - Less than 10 years & 74 & 18.5 & & \\
\hline 3 & 10- Less than 15 years & 77 & 19.3 & & \\
\hline 4 & More than 15 years & 190 & 47.5 & & \\
\hline $\begin{array}{l}\text { To } \\
\text { tal }\end{array}$ & & 400 & 100.0 & & \\
\hline
\end{tabular}

It is clear from Table (5) that distribution of the sample of employees according to experience in air transport and airlines comes at an average (3.00) towards job experience more than 10 years, with a standard deviation (1.119). Where experience more than 15 years $(47.5 \%)$ of the sample, followed by experience 10 years to less than 15 years $(19.3 \%)$ of the sample size, and then experience 5 years to less than 10 years (18.5\%). While experience less than 5 years $(14.8 \%)$ of the sample. That indicates the long experience of study sample in the field of airline business leading to the honesty of their views.

\section{6-2-2 work experience in the current airline}

Table (4): Distribution of employees according to work experience in the current airline 
Talent Management and its Role on Supporting the

- Competitiveness in the Airline Companies

\begin{tabular}{|c|c|c|c|c|c|}
\hline$\frac{2}{8}$ & $\begin{array}{c}\text { Experience in current } \\
\text { airline }\end{array}$ & $\frac{2}{8}$ & $\begin{array}{l}\text { Percent } \\
(\%)\end{array}$ & ב⿱⺈ & 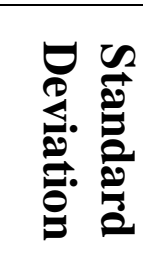 \\
\hline 1 & Less than 5 years & 68 & 17.0 & \multirow{5}{*}{2.91} & \multirow{5}{*}{1.137} \\
\hline 2 & 5 - Less than 10 years & 73 & 18.3 & & \\
\hline 3 & 10- Less than 15 years & 85 & 21.3 & & \\
\hline 4 & More than 15 years & 174 & 43.5 & & \\
\hline $\begin{array}{c}\text { Tot } \\
\text { al }\end{array}$ & & 400 & 100.0 & & \\
\hline
\end{tabular}

It is clear from Table (4) that distribution of the study sample of employees according to work experience in their current companies comes at an average (2.91) towards work experience more than10 years, with a standard deviation (1.137). Where experience more than 15 years $(43.5 \%)$ of the sample, followed by experience 10 years to less than 15 years $(21.3 \%)$ of the sample, and then experience 5 years to less than 10 years $(18.3 \%)$. While experience less than 5 years $(17.0 \%)$ of the sample. This also emphasizes long experience of the study sample in the field of airline business as shown in Table (4).

\section{6-2-3 Administrative level:}

Table (5): Distribution of employees according to administrative level

\begin{tabular}{|c|c|c|c|c|c|}
\hline$\frac{8}{8}$ & Administrative Level & $\frac{3}{8}$ & $\begin{array}{l}\text { Percent } \\
\quad(\%)\end{array}$ & $\underset{\substack{3 \\
\hdashline}}{3}$ & 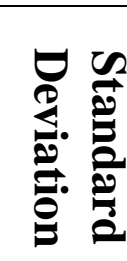 \\
\hline 1 & $\begin{array}{ll}\begin{array}{l}\text { Direct } \\
\text { (staff) }\end{array} & \text { Management } \\
\end{array}$ & 51 & 12.8 & \multirow{3}{*}{2.17} & \multirow{3}{*}{0.631} \\
\hline 2 & Middle Management & 229 & 57.3 & & \\
\hline 3 & Senior Mnagement & 120 & 30.0 & & \\
\hline
\end{tabular}


مجلة كلية السياحة والفنادق - ملحق العدد الخامس يونيوها.r الخاص بالمؤتتر العلمي الثاني

\begin{tabular}{|c|c|c|c|c|l|}
\hline $\begin{array}{c}\text { Tot } \\
\text { al }\end{array}$ & 400 & 100.0 & & \\
\hline
\end{tabular}

It is clear from Table (5) that distribution of the study sample of employees according to administrative level comes at an average (2.17) towards middle management, with a standard deviation (0.631). Where employees at middle management $(57.3 \%)$ of the sample, followed by employees at direct management $(30.0 \%)$ of the sample. While senior management $(12.8 \%)$ of the sample. This is because most of the study sample of heads of Human Resources departments and managers, as they are the best to deal with paragraphs of the questionnaire.

\section{6-2-4 Work Department:}

Table (6): Distribution of employees according to work department

\begin{tabular}{|c|c|c|c|c|c|}
\hline ڤి & $\begin{array}{c}\text { Work } \\
\text { Department }\end{array}$ & $\frac{2}{8}$ & Percent (\%) & בְּ & 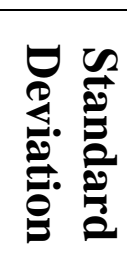 \\
\hline 1 & $\begin{array}{l}\text { Human } \\
\text { Resources. }\end{array}$ & 127 & 31.8 & \multirow{9}{*}{3.35} & \multirow{9}{*}{2.564} \\
\hline 2 & Ticketing. & 103 & 25.8 & & \\
\hline 3 & Sales. & 35 & 8.8 & & \\
\hline 4 & Accounting. & 16 & 4.0 & & \\
\hline 5 & Legal Affairs. & 8 & 2.0 & & \\
\hline 6 & Secretary. & 24 & 6.0 & & \\
\hline 7 & $\begin{array}{l}\text { Company } \\
\text { management. }\end{array}$ & 42 & 10.5 & & \\
\hline 8 & Others. & 45 & 11.3 & & \\
\hline $\begin{array}{c}\text { Tot } \\
\text { al }\end{array}$ & & 400 & 100.0 & & \\
\hline
\end{tabular}

It is clear from Table (6) that distribution of the study sample of employees according to work department shows that employees at 
Human Resources (31.8\%) of the sample because they are the best to deal with paragraphs with the questionnaire as mentioned in table (5), followed by Ticketing employees (25.8\%) of the sample. Then employees at other departments (yield planning, transit, traffic officer, commercial sector; planning, arrival and departure halls, and call centre) estimates (11.3\%), then employees at company management $(10.5 \%)$ of the sample. While employees at sales, accounting, secretary, and legal affairs; $(8.8 \%),(4.0 \%),(6.0 \%)$, and $(2.0 \%)$ respectively. This Indicates diversity of administrative departments to which the study sample belongs, leading to a variety of functional backgrounds of study sample.

\section{6-3 Airlines awareness of talent management as an administrative trend}

6-3-1 Awareness of airlines of the term talent management:

Table (7): Awareness of airlines sample of the term talent management

\begin{tabular}{|c|c|c|c|c|c|}
\hline$\frac{2}{8}$ & $\begin{array}{c}\text { Awareness of } \\
\text { TM }\end{array}$ & $\frac{3}{0}$ & Percent (\%) & 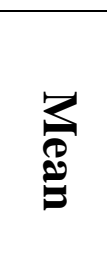 & 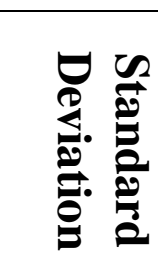 \\
\hline 1 & No. & 127 & 31.8 & \multirow{4}{*}{2.02} & \multirow{4}{*}{0.812} \\
\hline 2 & $\begin{array}{l}\text { Familiar with the } \\
\text { meaning not the } \\
\text { term itself. }\end{array}$ & 137 & 34.3 & & \\
\hline 3 & Yes. & 136 & 34.0 & & \\
\hline $\begin{array}{c}\text { Tot } \\
\text { al }\end{array}$ & & 400 & 100.0 & & \\
\hline
\end{tabular}

It is clear from Table (7) that awareness of the study sample of the term talent management comes at an average (2.02) towards familiar with the meaning not the term itself, with a standard deviation (0.812). Where employees who are familiar with the 


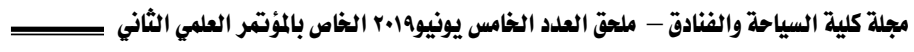

meaning not the term itself $(34.3 \%)$ of the sample, followed by employees who are aware of talent management (34.0\%) of the sample. While employees who are not aware of talent management $(31.8 \%)$ of the sample. Which shows that there is ambiguity of Talent Management to many employees which is also confirmed by (Seyam, 2013).

\section{6-3-2 Airlines sample apply talent management as an administrative trend:}

Table (8): Airlines apply TM as an administrative trend

\begin{tabular}{|c|c|c|c|c|c|}
\hline ̊̊ & $\begin{array}{c}\text { Application } \\
\text { of TM }\end{array}$ & $\frac{3}{3}$ & $\begin{array}{c}\text { Percent } \\
(\%)\end{array}$ & 胥 & 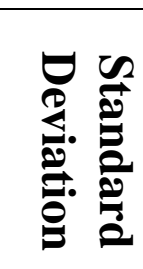 \\
\hline 1 & No. & 198 & 49.5 & \multirow{4}{*}{1.66} & \multirow{4}{*}{0.729} \\
\hline 2 & $\begin{array}{l}\text { To some } \\
\text { extent. }\end{array}$ & 141 & 35.3 & & \\
\hline 3 & Yes. & 61 & 15.3 & & \\
\hline Total & & 400 & 100.0 & & \\
\hline
\end{tabular}

It is clear from Table (8) that application of talent management from the study sample comes at an average (1.66) towards to some extent, with a standard deviation (0.729). As airlines who do not apply talent management $(49.5 \%)$ of the sample, followed by airlines who apply talent management to some extent which means that they apply talent management partially (35.3\%) of the sample. While airlines who apply talent management (15.3\%) of the sample. This refers that there is no attention to talent management in airlines in Arab Republic of Egypt, despite its significant importance.

\section{6-3-3 Awareness about other airlines apply this administrative trend:}


Talent Management and its Role on Supporting the

Competitiveness in the Airline Companies

Table (9): Awareness about others who apply this

administrative trend

\begin{tabular}{|c|c|c|c|c|c|}
\hline$\overbrace{0}^{2}$ & $\begin{array}{l}\text { Application } \\
\text { of other } \\
\text { airlines }\end{array}$ & 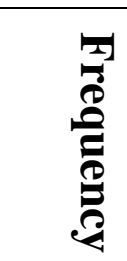 & $\begin{array}{c}\text { Percent } \\
(\%)\end{array}$ & $\stackrel{3}{3}$ & 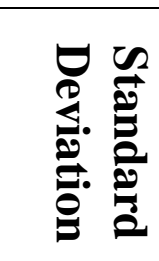 \\
\hline 1 & No. & 282 & 70.5 & \multirow{4}{*}{1.49} & \multirow{4}{*}{0.798} \\
\hline 2 & $\begin{array}{l}\text { To some } \\
\text { extent. }\end{array}$ & 41 & 10.3 & & \\
\hline 3 & Yes. & 77 & 19.3 & & \\
\hline Total & & 400 & 100.0 & & \\
\hline
\end{tabular}

It is clear from Table (9) that awareness of the study sample about application of other airlines of talent management comes at an average (1.49) towards to some extent, with a standard deviation (0.798). Where other airlines who do not apply talent management (70.5\%), followed by other airlines who apply talent management to some extent $(10.3 \%)$. While other airlines who apply talent management $(15.3 \%)$. According to these results there is also no interest in talent management in airlines in Arab Republic of Egypt as shown in table (8).

6-3-4 Intention to apply this administrative trend in the future if it is not applied:

Table (10): Intention to apply TM in the future if it is not applied

\begin{tabular}{|c|c|c|c|c|c|}
\hline$\frac{2}{2}$ & $\begin{array}{c}\text { Intention to } \\
\text { apply TM }\end{array}$ & 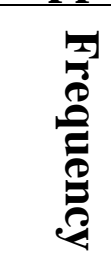 & $\begin{array}{c}\text { Percent } \\
(\%)\end{array}$ & $\stackrel{2}{3}$ & 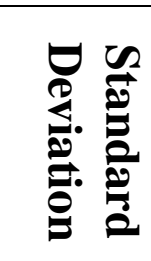 \\
\hline 1 & No. & 61 & 15.3 & \multirow[b]{2}{*}{2.26} & \multirow[b]{2}{*}{0.706} \\
\hline 2 & $\begin{array}{l}\text { To some } \\
\text { extent. }\end{array}$ & 174 & 43.5 & & \\
\hline
\end{tabular}




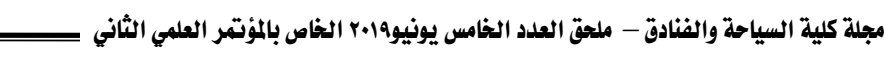

\begin{tabular}{|c|l|c|c|}
\hline 3 & Yes. & 165 & 41.3 \\
\hline Total & & 400 & 100.0 \\
\hline
\end{tabular}

It is clear from Table (10) that intention of study sample to apply talent management in the future comes at an average (2.26) towards to some extent, with a standard deviation (0.706). Where airlines who intent to apply talent management to some extent represent $(43.5 \%)$ of the sample, followed by airlines who intent to apply talent management $(41.3 \%)$. While airlines who do not intent to apply talent management $(15.3 \%)$.Some airlines have justified the possibility of applying talent management to some degree or inability to it due to the difficulty of implementation and weakness of their human resource potential. Hence, these companies can be assisted by providing an integrated talent management strategy to be applied.

\section{6-4 Assessment of the application of talent management in airlines}

6-4-1 Attention of airlines sample to talent identification: Table (11): Talent identification

\begin{tabular}{|l|c|c|}
\hline \multicolumn{1}{|c|}{ Talent identification } & Mean & $\begin{array}{c}\text { Standard } \\
\text { Deviation }\end{array}$ \\
\hline $\begin{array}{l}\text { 1-There are specific and clear criteria } \\
\text { for selecting talent. }\end{array}$ & 2.03 & 0.788 \\
\hline $\begin{array}{l}\text { 2-Objective measures for assessing } \\
\text { talent performance. }\end{array}$ & 1.94 & 0.888 \\
\hline $\begin{array}{l}\text { 3-There is a comprehensive talent } \\
\text { database. }\end{array}$ & 1.64 & 0.885 \\
\hline $\begin{array}{l}\text { General trend of talent identification } \\
\text { Result of the axis of talent } \\
\text { identification }\end{array}$ & $\begin{array}{l}\text { To some } \\
\text { extent }\end{array}$ & 0.757 \\
\hline
\end{tabular}

Table (11) shows that there is a relative difference in average for phrases of talent identification for the study sample from airlines; degrees of approval are to some extent with an average (1.87). Where the most agreed phrase for airlines is (There are specific and clear 
criteria for selecting talent in the company) with an average of (2.03), while the least agreed phrase is (There is a comprehensive talent database) with an average (1.64). The overall average of this dimension is to some extent due to the lack of a comprehensive talent database, while there is a database for the company as a whole, as well as lack of standards for evaluating talent performance and lack of criteria for talent selection, which is also consistent with the study of (Ziadi, 2016).

\section{6-4-2 Attention of airlines sample to talent attraction:}

Table (12): Talent attraction

\begin{tabular}{|l|c|c|}
\hline \multicolumn{1}{|c|}{ Talent attraction } & Mean & $\begin{array}{c}\text { Standard } \\
\text { Deviation }\end{array}$ \\
\hline $\begin{array}{l}\text { 4-Interest to attract new talent and } \\
\text { integrate it into business. }\end{array}$ & 1.85 & 0.829 \\
\hline $\begin{array}{l}\text { 5-Search for talent from within the } \\
\text { company itself. }\end{array}$ & 2.13 & 0.823 \\
\hline $\begin{array}{l}\text { 6-Provide rewarding salaries and } \\
\text { incentives to attract talented people. }\end{array}$ & 1.47 & 0.538 \\
\hline $\begin{array}{l}\text { 7-Opportunities for promotion for } \\
\text { talented people and who introduces new } \\
\text { ideas for the company. }\end{array}$ & 1.90 & 0.722 \\
\hline $\begin{array}{l}\text { 8-Social, health and other services that } \\
\text { attract talent. }\end{array}$ & 2.01 & 0.854 \\
\hline $\begin{array}{l}\text { General trend of talent attraction } \\
\text { Result of the axis of talent attraction }\end{array}$ & $\begin{array}{c}\text { To some } \\
\text { extent }\end{array}$ & \\
\hline
\end{tabular}

It is clear from table (12) that there is a relative difference in average for phrases of talent attraction for the study sample from airlines; degrees of approval are to some extent with an average (1.87). Where the most agreed phrases for airlines are (Searching for talent from within the company itself) and (There are Social, health and other services that attract talent) with averages (2.13), (2.01) respectively. While the least agreed phrase is (Providing 


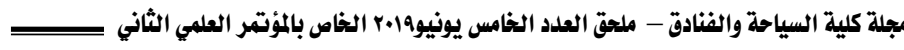

rewarding salaries and incentives to attract talented people) with an average (1.47). The overall average of this dimension is to some extent due to the lack of interest of airlines for attracting talent. According to these results it is clear that airlines neglect the importance of attracting talent, although attracting and retaining talent leads to ensuring business continuity and improving competitiveness as mentioned by (Mohammed, 2015).

6-4-3 Attention of airlines sample to talent retention:

Table (13): Talent retention

\begin{tabular}{|l|c|c|}
\hline \multicolumn{1}{|c|}{ Talent retention } & Mean & $\begin{array}{c}\text { Standard } \\
\text { Deviation }\end{array}$ \\
\hline $\begin{array}{l}\text { 9-Interest to the social and functional } \\
\text { status of employees with outstanding and } \\
\text { creative abilities. }\end{array}$ & 1.87 & 0.733 \\
\hline $\begin{array}{l}\text { 10-Provide moral and material incentives } \\
\text { to innovators. }\end{array}$ & 1.71 & 0.712 \\
\hline $\begin{array}{l}\text { 11-Seek to establish good and positive } \\
\text { relations between the talented themselves } \\
\text { on one hand and between them and } \\
\text { management of the company on the other } \\
\text { hand. }\end{array}$ & 2.24 & 0.774 \\
\hline $\begin{array}{l}\text { 12-Business climate stimulates } \\
\text { renovation and innovation at work. }\end{array}$ & 1.83 & 0.723 \\
\hline General trend of talent retention & 1.91 & 0.491 \\
\hline $\begin{array}{l}\text { Result of the axis of talent retention } \\
\text { extent }\end{array}$ & To some & \\
\hline
\end{tabular}

It is clear from table (13) that there is a relative difference in average for phrases of talent retention for the study sample from airlines; degrees of approval are to some extent with an average (1.91). Where the most agreed phrase for airlines is (Seeking to establish good and positive relationships between the talented themselves on one hand and between them and management of the company on the other hand) with an average (2.24). While the 
least agreed phrase is (Providing moral and material incentives to innovators who are currently working in the company) with an average (1.71), which is confirmed by results of table (12) where the least agreed statement is also (providing the company for rewarding incentives), indicating lack of interest of companies to provide incentives to their employees. The overall average of this dimension is to some extent due to lack of interest of airlines for retaining talent, which is consistent with the results of the study of (Aljarrah, et al., 2015), which also found a clear failure by the university towards its talents by granting rewards or incentives, making the working environment less competitive, which leads talented to search for a more interactive and more challenging environment and thus leave their work.

6-4-4 Airlines sample's quest for talent development:

Table (14): Talent development

\begin{tabular}{|l|c|c|}
\hline \multicolumn{1}{|c|}{ Talent development } & Mean & $\begin{array}{c}\text { Standard } \\
\text { Deviation }\end{array}$ \\
\hline $\begin{array}{l}\text { 13-Keen to measure the needs of talented } \\
\text { to training courses for raising their } \\
\text { competence. }\end{array}$ & 2.19 & 0.785 \\
\hline $\begin{array}{l}\text { 14-There are training programs for } \\
\text { developing talented and raising their } \\
\text { competence based on their needs. }\end{array}$ & 0.964 \\
\hline $\begin{array}{l}\text { 15-Management uses orientation and } \\
\text { continuous learning programs. }\end{array}$ & 2.31 & 0.818 \\
\hline $\begin{array}{l}\text { 16-Request from employees some new } \\
\text { and innovative tasks. }\end{array}$ & 2.14 & 0.784 \\
\hline $\begin{array}{l}\text { 17-Put high competencies (talented) in } \\
\text { leadership positions appropriate to their } \\
\text { abilities. }\end{array}$ & 2.16 & 0.667 \\
\hline $\begin{array}{l}\text { 18-Revive the spirit of competition among } \\
\text { employees in order to work on self- } \\
\text { development. }\end{array}$ & & \\
\hline
\end{tabular}




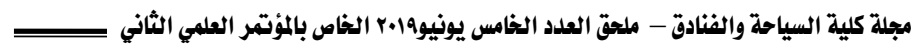

\begin{tabular}{|l|c|c|}
\hline General trend of talent development & 2.13 & 0.473 \\
\hline Result of the axis of talent development & $\begin{array}{c}\text { To } \\
\text { some } \\
\text { extent }\end{array}$ & \\
\hline
\end{tabular}

It is clear from table (14) that there is a relative difference in average for phrases of talent development; degrees of approval are to some extent with an average (2.13). Where the most agreed phrases for airlines are (Management uses orientation and continuous learning programs) with an average (2.31). While the least agreed phrases are (There are training programs for developing talented and raising their competence based on their needs), and (Revive the spirit of competition among employees in order to work on self-development) with averages (1.97), (2.01) respectively. According to these results, the overall average of this dimension is to some extent. This is consistent with the study of (Egerova, et al, 2013) that found weakness in investment into the training and developing employees in T-systems Slovakia S.R.O due to the insufficient identification of talents at the beginning, As well there is a need for tailoring training courses to the needs of the targeted group of talents.

6-4-5 level of application of talent management strategies as whole

Table (15): level of application of TM strategies as whole in airlines from point of view of the study sample

\begin{tabular}{|l|c|c|c|}
\hline \multicolumn{1}{|c|}{ Strategies } & Mean & $\begin{array}{c}\text { Standard } \\
\text { Deviation }\end{array}$ & $\begin{array}{c}\text { Degree of } \\
\text { approval }\end{array}$ \\
\hline Talent Identification. & 1.87 & 0.757 & To some extent \\
\hline Talent Attraction. & 1.87 & 0.599 & To some extent \\
\hline Talent Retention. & 1.91 & 0.491 & To some extent \\
\hline Talent Development. & 2.13 & 0.473 & To some extent \\
\hline $\begin{array}{l}\text { Level of application of } \\
\text { Talent Management }\end{array}$ & 1.95 & 0.492 & To some extent \\
\hline
\end{tabular}


strategies as whole.

It is clear from Table (15) that the overall level of application of talent management strategies in the airlines comes at an average (1.95); degrees of approval are to some extent. Where the averages of the four strategies ranged between (1.87) and (2.13), that Talent development strategy ranked first with an average (2.31), followed by Talent retention strategy with an average (1.91), While Talent identification and Talent attraction ranked last with average for both of them (1.87). Table (15) also shows that standard deviations ranged between (0.473) and (0.757) which indicates rapprochement of responses of the study sample. According to these results level of application of Talent Management strategies in the airlines in Egypt is to some exent whis is consistent with study of (Aljarrah, et al., 2015); which found that level of application of Talent management strategies in Official Jordanian Universities is medium. And it is also consistent with the study of (Salih \& Alnaji, 2014); which found that talent management is still below the level of ambition showing that Jordanian Telecommunications Companies need to pay attention to talent management if they wish to maintain proper customer interaction.

6-5 Interest of airlines in measuring their competitiveness and identifying factors that affect them

6-5-1 Interest of airlines sample to measure their competitiveness:

Table (16): Airlines sample's Interest to measure their competitiveness

\begin{tabular}{|c|c|c|c|c|c|}
\hline ̊̊ & $\begin{array}{c}\text { Interested to } \\
\text { measure } \\
\text { competitivenes } \\
\text { s }\end{array}$ & $\frac{1}{2}$ & $\begin{array}{c}\text { Percent } \\
(\%)\end{array}$ & $\begin{array}{l}3 \\
\mathfrak{3} \\
\mathfrak{3}\end{array}$ & 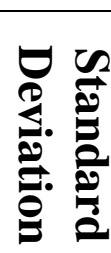 \\
\hline 1 & No. & 13 & 3.3 & & \\
\hline
\end{tabular}




\begin{tabular}{|c|c|c|c|c|c|}
\hline 2 & To some extent & 149 & 37.3 & \multirow[t]{3}{*}{2.56} & \multirow[t]{3}{*}{0.558} \\
\hline 3 & Yes. & 238 & 59.5 & & \\
\hline Total & & 400 & 100.0 & & \\
\hline
\end{tabular}

It is clear from Table (16) that airlines sample's Interest to measure their competitiveness comes at an average (2.56) towards yes, with a standard deviation (0.558). Where airlines that interest to measure their competitiveness represent percentage $(59.5 \%)$ of the sample, followed by airlines who measure their competitiveness to some extent (37.3\%). While airlines that do not interest to measure their competitiveness (3.3\%). According to these results, airlines in Egypt are interested to measure their competitiveness.

\section{6-5-2 Indicators used by airlines sample to measure their competitiveness:}

Table (17): Indicators used by sample to measure their competitiveness

\begin{tabular}{|c|l|c|c|}
\hline Code & Indicator & Frequency & Percent (\%) \\
\hline 1 & Profitability. & 232 & 38.2 \\
\hline 2 & Service cost. & 112 & 18.4 \\
\hline 3 & Market share. & 200 & 32.4 \\
\hline 4 & Productivity. & 64 & 10.5 \\
\hline 5 & Other. & 0 & 0.00 \\
\hline Total & & 608 & 100.0 \\
\hline
\end{tabular}

* Possibility to choose more than one answer

It is clear from Table (17) that indicators used by airlines sample that are interested to measure their competitiveness are profitability indicator which ranked first with percentage (38.2) of the sample, followed by market share indicator $(32.4 \%)$. While service cost and productivity indicators ranked last with percentages (18.4), (10.5) respectively.According to these results, the most used indicators by airlines in Egypt to measure their competitiveness are profitability and market share indicators. 
6-5-3 Factors that positively affect competitiveness of airlines sample:

Table (18): Factors that positively affect competitiveness of the study sample

\begin{tabular}{|c|l|c|c|}
\hline Code & \multicolumn{1}{|c|}{ factor } & Frequency & Percent (\%) \\
\hline 1 & Service quality. & 304 & 25.2 \\
\hline 2 & Low cost. & 200 & 16.6 \\
\hline 3 & $\begin{array}{l}\text { Modern management } \\
\text { techniques. }\end{array}$ & 248 & 20.5 \\
\hline 4 & $\begin{array}{l}\text { Effective marketing } \\
\text { policies. }\end{array}$ & 184 & 15.2 \\
\hline 5 & $\begin{array}{l}\text { Privileged human } \\
\text { resources. }\end{array}$ & 272 & 25.5 \\
\hline 6 & $\begin{array}{l}\text { Other. } \\
\text { Total }\end{array}$ & 1208 & 100.0 \\
\hline
\end{tabular}

* Possibility to choose more than one answer

It is clear from Table (18) that factors affect positively airlines sample's competitiveness are privileged human resources and service quality which ranked first with percentages (25.5), (25.2) respectively, followed by modern management techniques $(20.5 \%)$. While low cost and effective marketing policies ranked last with percentages (16.6), (15.2) respectively. According to these results, the most positively effected factors of airlines's competitiveness are privileged human resources and service quality. This is consistent with the study of (Ahmed, 2016) that found human resources - especially talented - contribute to the achievement of competitive advantage in their organizations because they innovate in their field and they have the ability to make the right decisions to achieve goals.
6-5-4 Management trends that positively affect competitiveness of airlines sample: 


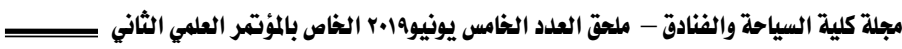

Table (19): Management trends that positively affect the competitiveness

\begin{tabular}{|c|l|c|c|}
\hline Code & \multicolumn{1}{|c|}{ Management trend } & Frequency & Percent (\%) \\
\hline 1 & Knowledge Management. & 224 & 21.4 \\
\hline 2 & Time Management. & 136 & 13.0 \\
\hline 3 & Talent Management & 304 & 29.0 \\
\hline 4 & Change Management. & 192 & 18.3 \\
\hline 5 & $\begin{array}{l}\text { Management } \\
\text { Objectives. }\end{array}$ & 192 & 18.3 \\
\hline 6 & Other. & 0 & 00.0 \\
\hline Total & & 1048 & 100.0 \\
\hline
\end{tabular}

* Possibility to choose more than one answer

It is clear from Table (19) that airlines sample's point of view of management trends positively affect their competitiveness that Talent Management ranked first with percentage (29.0) of the sample, followed by Knowledge Management with (21.4\%). While Change Management, Management by Objectives and Time Management ranked last with percentages (18.3), (18.3), (13.0) respectively. According to these results, Talent Management is the most positively effected management trend on competitiveness of airlines. This is consistent with the study of (Ahmed, 2016) that found Talent Management particularly needs to be considered as a differentiating strategic capability that can offer real and esssential competitive advantage.

6-6 The impact of talent management application on competitiveness of airlines

6-6-1 Impact on airline sample's efficiency and excellence:

Table (20): Impact on airline sample's efficiency and excellence

\begin{tabular}{|c|c|c|}
\hline Impact on efficiency and excellence & Mean & $\begin{array}{c}\text { Standard } \\
\text { Deviation }\end{array}$ \\
\hline 1 -Various departments have specialized & 2.63 & 0.565 \\
\hline
\end{tabular}


Talent Management and its Role on Supporting the

- Competitiveness in the Airline Companies

expertise in its field of business.

2-Talented use available resources to make the best possible use.

3-Airline has talented who are able to use modern technology.

4-All the methods and strategies defined

by your airline to develop the efficiency of air transport operations are followed.

General trend of efficiency and excellence

Result of the axis of efficiency and excellence

It is clear from table (20) that there is a slight difference in averages of the terms of impact of Talent Management on efficiency and excellence for the study sample from airlines; the overall average (2.57) refers to that there is an impact of Talent Management on efficiency and excellence. Where the most agreed phrases for airlines are (All the methods and strategies defined by airline to develop the efficiency of air transport operations are followed) and (Various departments have specialized expertise in its field of business) with averages (2.65), (2.63) respectively. According to these results it is clear that there is an impact of talent management on efficiency and excellence of airlines.

6-6-2 Impact on service quality provided by airlines sample:

Table (21): Impact on service quality provided by airlines sample

\begin{tabular}{|l|c|c|}
\hline \multicolumn{1}{|c|}{ Impact on service quality } & Mean & $\begin{array}{c}\text { Standard } \\
\text { Deviation }\end{array}$ \\
\hline $\begin{array}{l}\text { 5-Employees are keen to excel in the } \\
\text { performance of work. }\end{array}$ & 2.69 & 0.578 \\
\hline $\begin{array}{l}\text { 6-Work is performed in quantity and } \\
\text { quality required together. }\end{array}$ & 2.69 & 0.511 \\
\hline
\end{tabular}




\begin{tabular}{|c|c|c|}
\hline $\begin{array}{l}\text { Job functions are performed according } \\
\text { the required quality standards. }\end{array}$ & 2.73 & 0.446 \\
\hline $\begin{array}{l}\text { Service is provided in a quality that } \\
\text { eets the needs and satisfaction of the } \\
\text { sssengers. }\end{array}$ & 2.71 & 0.536 \\
\hline $\begin{array}{l}\text { Every employee is fully aware of his } \\
\text { ork. }\end{array}$ & 2.75 & 0.435 \\
\hline eneral trend of service quality & 2.71 & 0.367 \\
\hline Result of the axis of service quality & & $\mathrm{les}$ \\
\hline \multicolumn{3}{|c|}{$\begin{array}{l}\text { It is clear from table (21) that there is a slight difference in } \\
\text { averages of the phrases of impact of Talent Management on } \\
\text { service quality provided by airlines sample; the overall average } \\
\text { (2.71) refers to that there is an impact of Talent Management on } \\
\text { service quality. Where the most agreed phrases for airlines are } \\
\text { (Every employee is fully aware of his work, enabling him to } \\
\text { respond to travelers' inquiries) and (Job functions are performed } \\
\text { according to the required quality standards) with averages ( } 2.75 \text { ) } \\
\text { (2.73) respectively. According to these results it is clear that there } \\
\text { is an impact of talent management on service quality provided by } \\
\text { airlines. } \\
\text { 6-6-3 Impact on distinguished creativity standards within } \\
\text { airlines sample: } \\
\text { Table (22): Impact on distinguished creativity standards }\end{array}$} \\
\hline $\begin{array}{l}\text { Impact on distinguished creativity } \\
\text { standards }\end{array}$ & Mean & $\begin{array}{l}\text { Standard } \\
\text { Deviation }\end{array}$ \\
\hline $\begin{array}{l}\text { rages employees to } \\
\text { ew ideas. }\end{array}$ & 2.38 & 0.669 \\
\hline $\begin{array}{l}\text { 11-Every employee makes every effort to } \\
\text { provide innovative ideas and work } \\
\text { methods. }\end{array}$ & 2.56 & 0.541 \\
\hline $\begin{array}{l}\text { 12-Your airline takes on all creative } \\
\text { applicable initiatives provided by }\end{array}$ & 2.26 & 0.533 \\
\hline
\end{tabular}


Talent Management and its Role on Supporting the

- Competitiveness in the Airline Companies

\begin{tabular}{|l|c|c|}
\hline employees. & & 0.448 \\
\hline $\begin{array}{l}\text { General trend of distinguished creativity } \\
\text { standards }\end{array}$ & 2.43 & 0.448 To some extent \\
\hline $\begin{array}{l}\text { Result of the axis of distinguished } \\
\text { creativity standards }\end{array}$ & \multicolumn{2}{|c|}{} \\
\hline
\end{tabular}

It is clear from table (24) that there is a slight difference in averages of the phrases of impact of Talent Management on distinguished creativity standards within airlines sample; the overall average (2.43) refers to that there is an impact of Talent Management on distinguished creativity standards. Where the most agreed phrase for airlines is (Every employee makes every effort to provide innovative ideas and creative work methods) with an average (2.56). According to these results it is clear that there is an impact of talent management on service distinguished creativity standards within airlines.

6-6-4 Impact on providing information and responding to demands of airlines sample's clients:

Table (23): Impact on providing information and responding to demands

\begin{tabular}{|c|c|c|}
\hline $\begin{array}{c}\text { providing information and responding to } \\
\text { demands }\end{array}$ & Mean & $\begin{array}{l}\text { Standard } \\
\text { Deviation }\end{array}$ \\
\hline $\begin{array}{l}\text { 13-Every employee has the skill to provide } \\
\text { information to clients before actually } \\
\text { delivering services. }\end{array}$ & 2.81 & 0.393 \\
\hline 14-Employees have communication skills. & 2.81 & 0.395 \\
\hline $\begin{array}{l}\text { 15- Employees are concerned about demans } \\
\text { and needs of clients and transfered them to } \\
\text { airline's management. }\end{array}$ & 2.91 & 0.354 \\
\hline $\begin{array}{l}\text { General trend of providing information an } \\
\text { responding to demands }\end{array}$ & 2.84 & 0.277 \\
\hline $\begin{array}{l}\text { Result of the axis of providing information } \\
\text { an responding to demands }\end{array}$ & & Yes \\
\hline
\end{tabular}


It is clear from table (23) that there is a slight difference in averages of the phrases of impact of Talent Management on providing information and responding to demands of airlines sample's clients; the overall average (2.84) refers to that there is an impact of Talent Management on providing information and responding to demands. Where the most agreed phrase for airlines is (Employees are concerned about demans and needs of clients and transfered them to airline's management to make improvements in services provided.) with an average (2.91). According to these results it is clear that there is an impact of talent management on providing information and responding to demands of airlines' clients.

\section{6-6-5 The overall impact of talent management application on competitiveness of airlines}

Table (24): The overall impact of talent management on competitiveness

\begin{tabular}{|l|c|c|c|}
\hline \multicolumn{1}{|c|}{$\begin{array}{c}\text { Impact on airlines } \\
\text { competitiveness }\end{array}$} & Mean & $\begin{array}{c}\text { Standard } \\
\text { Deviation }\end{array}$ & $\begin{array}{c}\text { Degree of } \\
\text { approval }\end{array}$ \\
\hline $\begin{array}{l}\text { Efficiency and } \\
\text { excellence. }\end{array}$ & 2.57 & 0.472 & Yes \\
\hline Service quality. & 2.71 & 0.367 & Yes \\
\hline $\begin{array}{l}\text { Distinguished creativity } \\
\text { standards. }\end{array}$ & 2.43 & 0.448 & To some extent \\
\hline $\begin{array}{l}\text { Providing information } \\
\text { and responding to } \\
\text { demands. }\end{array}$ & 2.84 & 0.277 & Yes \\
\hline $\begin{array}{l}\text { Overall impact of Talent } \\
\text { Management on airlines } \\
\text { competitiveness. }\end{array}$ & 2.64 & 0.310 & Yes \\
\hline
\end{tabular}

It is clear from Table (24) that the overall impact of talent management application on competitiveness of airlines comes at an average (2.64); degrees of approval refer to that there is an impact of talent management on airlines's copmetitiveness. Where 
the averages of the four impacts ranged between (2.43) and (2.84), that Providing information and responding to demands ranked first with an average (2.84), followed by Service quality as well efficiency and excellence with averages (2.71), (2.57) respectively. While distinguished creativity standards ranked last with an average (2.43). Table (24) also shows that standard deviations ranged between (0.277) and (0.472) which indicates approchement of responses of the study sample.

According to these results, there is an impact of talent management application on airlines competitiveness whis is consistent with study of (Eva, 2015); which found that talent management is of significant important issue for the organization due to its competitive advantage. And it is also consistent with the study of (Nazzal, 2016); which found that there is a direct statistically significant impact of talent management in enhancing competitiveness in IT companies in Jordan, which shows its importance in improving the company's operations through the development of employees' skills through their participation in decision-making processes.

\section{6-7 Validity of hypotheses test}

Test of hypotheses is a useful tool for predicting, planning and making decisions. (T-Test) was used to detect a significant difference in the mean of the study population from which the sample was drawn from a fixed value through the SPSS program, as follows:

\section{6-7-1 First Hypothesis}

- Null hypothesis (H0): There are Talent Management strategies in airlines.

- Alternative Hypothesis (H1): Lack of strategies of Talent Management in airlines.

Where the mean of population was compared at a significance level (0.05), Table (25) shows the results of the test as follows: 
Table (25): $\mathrm{T}$-test for first hypothesis

\begin{tabular}{|c|c|c|c|c|c|c|}
\hline Mean & 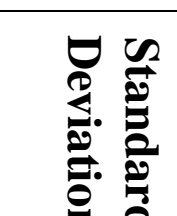 & $\begin{array}{l}\text { Standard } \\
\text { Error } \\
\text { Mean }\end{array}$ & 章 & $\begin{array}{r}95 \% \mathrm{Cc} \\
\text { interval } \mathrm{f} \\
\mathrm{me}\end{array}$ & $\begin{array}{l}\text { fidence } \\
\text { the two } \\
\text { ns }\end{array}$ & 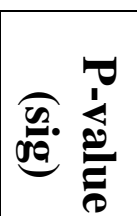 \\
\hline 3.8231 & 0.92870 & 0.04644 & 82.333 & $\begin{array}{c}\text { Minimum } \\
3.7318\end{array}$ & $\begin{array}{c}\text { Maximum } \\
3.9144\end{array}$ & 0. \\
\hline
\end{tabular}

It is clear from Table (25) that the probability of significance $(\mathrm{P})$ is less than significance level (0.05) and that value of $\mathrm{T}$ is less than the value of the test and thus the null hypothesis is rejected and alternative hypothesis is accepted that "there is lack of strategies of talent management in airlines".

\section{6-7-2 Second Hypothesis}

Null hypothesis (H0): There is no statistically significant relationship between talent management and supporting competitiveness in airlines.

- Alternative Hypothesis (H1): Existence of a statistically significant relationship between talent management and supporting competitiveness in airlines.

To validate this hypothesis, researcher used:

-Simple linear regression analysis to measure the impact of talent management dimensions on the dimensions of enhancing competitiveness in airlines.

- The results of correlative relationships of talent management dimensions with the dimensions of enhancing competitiveness in airlines.

To validate the effect of applying talent management on enhancing competitiveness, simple linear regression analysis at a significance level (0.05) was used. The results are as shown in the following table: 
Talent Management and its Role on Supporting the

Table (26):

Simple linear regression analysis of talent management on competitiveness of airlines

\begin{tabular}{|l|c|c|c|c|c|c|l|}
\hline $\begin{array}{l}\text { Independent } \\
\text { Variable }\end{array}$ & $\begin{array}{c}\text { Beta } \\
\boldsymbol{\beta}\end{array}$ & $\mathbf{T}$ & $\begin{array}{c}\mathbf{T} \\
\text { Sig. }\end{array}$ & $\mathbf{R}$ & $\mathbf{R}^{2}$ & $\mathbf{F}$ & $\begin{array}{l}\mathbf{F} \\
\text { Sig. }\end{array}$ \\
\hline $\begin{array}{l}\text { Talent } \\
\text { Management }\end{array}$ & 0.559 & 13.446 & 0.000 & 0.559 & 0.312 & 180.802 & 0.000 \\
\hline
\end{tabular}

Dependent Variable: Supporting Competitiveness

It is clear from table (26) that coefficient of determination $\left(\mathrm{R}^{2}\right)$ indicates that the independent variable (talent management) accounts for $31 \%$ of the change in the dependent variable (supporting competitiveness). It is also shown from the table that values of F Sig. and T Sig. are less than significance level (0.05), leading to the rejection of the null hypothesis and acceptance of the alternative hypothesis that "there is a statistically significant relationship between Talent Management and supporting competitiveness in airlines".

The following is a regression model:

$$
\mathrm{Y}=\mathrm{b} 0+\mathrm{b} 1 \mathrm{X}
$$

Supporting competitiveness $=1.946+0.352$ Talent Management Correlation analysis between the independent variable and the dependent variable also was used by calculating Pearson correlation coefficient and Spearman correlation coefficient to illustrate the correlation between the two variables and support the results obtained from the regression analysis. As shown in the following table:

Table (27):

Correlation between Talent Management and Supporting Competitiveness

\begin{tabular}{|c|c|c|}
\hline \multirow{2}{*}{$\begin{array}{l}\text { Dependent } \\
\text { Variable } \\
\text { Independent Variable }\end{array}$} & \multicolumn{2}{|c|}{ Supporting Competitiveness } \\
\hline & Pearson correlation & 0.559 \\
\hline
\end{tabular}




\begin{tabular}{|c|c|c|}
\hline \multirow[t]{3}{*}{ Talent Management } & Sig.(2-tailed) & 0.000 \\
\hline & Spearman correlation & 0.517 \\
\hline & Sig.(2-tailed) & 0.000 \\
\hline
\end{tabular}

**Correlation is significant at the 0.01 level (2-tailed).

Table (27) shows that the value of Pearson correlation coefficient, which reached $(0.559)$ is a statistically significant at the level of significance 0.01 with statistically significance (0.000), which indicates a direct correlation between the two variables. Spearman correlation coefficient was also calculated at value (0.517), which is statistically significant at the level of significance $(0.01)$ with statistically significance $(0.00)$, which also indicates a direct correlation between the two variables. This means that if talent management is applied, the output will be supporting the competitiveness of airlines.

\section{Results}

1- There is an ambiguity of Talent Management in many airlines in Arab Republic of Egypt.

2- Lack of a comprehensive talent database, while there is a database for the company as a whole, as well as lack of standards for evaluating talent performance and lack of criteria for talent selection.

3-Airlines neglect the importance of attracting talent, although attracting and retaining talent leads to ensuring business continuity and improving competitiveness..

4- Lack of interest of airlines for retaining talent, making the working environment less competitive, which leads talented to search for a more interactive and more challenging environment and thus leave their work.

5-Weakness in investment into the training and developing employees due to the insufficient identification of talents at the beginning. 
6-Some airlines have justified their inability to apply talent management due to the difficulty of implementation and weakness of their human resource potential.

7- Most of Arab and Foreign studies agreed that there is confusion between talent management and strategic human resource management concepts because of overlapping some activities and strategies applied to both concepts which drive to dispersion of organizations towards the applied practices of the two concepts.

8- The concept of talent management is the key to success of companies in era of globalization. As a form of investment, individuals are seen as the main source of development and innovation.

9- Airlines in Egypt are interested to measure their competitiveness; the most used indicators are profitability and market share indicators.

10- The most positively effected factors of airlines's competitiveness are privileged human resources and service quality, because they innovate in their field and they have the ability to make the right decisions to achieve goals.

11- Talent Management is the most positively affected management trend on competitiveness of airlines, which particularly needs to be considered as a differentiating strategic capability that can offer real and esssential competitive advantage. 12- There is lack of strategies of talent management in airlines in Arab Republic of Egypt.

13- There is a statistically significant relationship between Talent Management and supporting competitiveness in airlines.

Recommendations

1 - Necessity to create an organizational culture on the importance of human talent management and its role in supporting competitive advantage through the participation of senior and middle management in workshops and conferences to enhance 


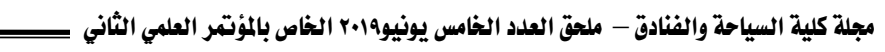

their understanding of the talent management system and how to implement its components.

2- Establishing precise and clear criteria for measuring talent and forming a database for talented in airlines.

3 - There is a need for tailoring training courses to the needs of the targeted group of talents.

4-Necessity for organizations to make extraordinary efforts to build effective, comprehensive and practical talent strategies that ensure employee retention, not only to attract talent, that drive productivity and business performance.

5- Attention to develop strategies for retaining talents, not only to attract them, by providing a supportive environment that works to satisfy their needs, raise their skills, raise their job satisfaction and raise their organizational affiliation.

6- Attention to motivate and encourage talented continuously through salaries and indirect compensation.

7- Necessity to provide a work environment that allows creativity and innovation through the experimentation of innovative ideas and creative solutions provided by the employees and put them into practice.

8-Providing an excellent administrative structure and infrastructure for airlines that meet the requirements of a changing and highly competitive work environment.

9- Need for experts and specialists in administration to provide an integrated talent management strategy to help airlines to apply talent management properly.

${ }^{1}$ Professor in Tourism Studies Department Faculty of Tourism and Hotels Mansoura University

2 Professor in Tourism Studies Department Faculty of Tourism and Hotels Mansoura University

${ }^{3}$ Assistant Lecturer in Tourism Studies Department Faculty of Tourism and Hotels Mansoura University 


\section{References}

Ahmed, H, K. (2016): The Impact of Talent Management on the Competitive Advantage in the Organizations, 37th ISERD International Conference, Abu Dhabi- UAE.

Aljarrah, S, A., Daoud, J., and Abu-Doleh.(2015): The Impact of Applying Talent Management Strategies in Enhancing the Organizational Affiliation of the Faculty Members in Jordanian Public Universities, Jordan Journal of Businesss Administration, Vol.11, No.2.

Atan, T. and Stapf, D. (2017): Concepualizing Talent Management, International Journal of Economics, Commerce and Management, Issue 8 (v), United Kingdom, August.

Banarjee, E, J. (2014): Describes and Deferentiate between Talent Management and Human Resource Management, Adventist International Institute of Advanced Studies, Cavite- Philippines.

Börjesson, E., and Tyskbo, D. (2015): Sorting Talents Out: Talent identification and its consequences, Master Degree Project, School of Business, Economics and Law, university of Gothenburg- Sweden.

Campbell, V. and Hirsh, W. (2013): Talent Management: A FourStep Approach, Institute for Employment Studies, Brighton- UK. Cegliński, P. (2016): The Concept of Competitive Advantages. Logic, sources and durability, Journal of Positive Management, Vol.7, No. 3.

DANILINA, E, I., REZNIKOVA, O, S., VERNA, V, V., \& GANIEVA, A,. K. (2017): Prospects for introducing the talent management concept into russian companies, Revista ESPACIOS, vol.38, No.48.

Egerova, D., Eger, L., \& Jirincova, M. (2013): Integrated Talent Management-Challenge and Future for Organizations in Visegrad Countries, $1^{\text {st }}$ Edition, NAVA, Plzen-Czech Republic. 
Eva, T, P. (2015): Talent Management A Key to Success in Any Organisation - Perspective from Bangladesh, The International Journal of Business and Management, Vol.3, No.12.

Fitzgerald, M. (2014): Talent and Talent Management Insights, NHS Leadership Academy, UK.

Gallardo, G, E., Cruz, T, F., and Dries, N. (2013): What is the Meaning of 'Talent' in the World of Work?, Human Resources Management Review 23, Elsevier, Oxford- UK, December.

Hewitt Associates and Human Capital Institute (2008): The State of Talent Management: Today's Challenges, Tomorrow's Opportunities, Human Capital Institute, New York- USA.

Hughes, J,C., and Rog, E. (2008): Talent management: A strategy for improving employee recruitment, retention and engagement within hospitality organizations, International Journal of Contemporary Hospitality Management, Vol. 20, No. 7.

Kilinc, I., Oncu, M. A., \& Tasgit, Y. E. (2012). A study on the competition strategies of the airline companies in Turkey, Tourismos: An international multidisciplinary journal of tourism, Vol.7, No.1.

Merlevade, P. (2014): Talent Management- A Focus on Excellence: Managing Human Resources in a Knowledge Economy, First Edition, Bookboon, London- UK.

Mohammed, A. (2015): The Impact of Talent Management on Employee Engagement, Retention and Value Addition in achieving Organizational Performance, International Journal of Core Engineering \& Management, Vol. 1, No.12.

Nazzal, H. (2016): The Impact of Competitive Innovation Strategies on Enhancing Competitiveness in Enhancing Competitive Abilities in Information Technology Companies in Jordan - Talent Management as a Mediator, Master Thesis, Business College, Middle East University, Amman, Jordan. 
O'Callaghan, A. (2008): Talent Management Review, FASSET, Johannesburg- Gauteng.

Phillips, D, R., and Roper, K, O. (2009): A framework for talent management in real estate, Journal of Corporate Real Estate, Vol. 11, No.1.

Pollard, S. (2013): Talent Development and Succession Planning for Sustainable Airport Growth, Available at http://www.aciasiapac.aero/services/main/17/upload/service/17/self/55cc67ce6b8 73.pdf, (Accessed on: 16/11/2018).

Radwan, M, A. (2012): Talent Management in the Organization, First Edition, Arab Group for Training and Publishing, CairoEgypt.

Roy, S. (2013): Flying Low: HR Challenges in the Airline Industry, IPBJ: International Postgraduate Business Journal, Vol. 5, No.1.

Salih, A. A., \& Alnaji, L. (2014): The impact of talent management in enhancing organizational reputation: an empirical study on the Jordanian telecommunications companies, Journal of Applied Business Research, Vol. 30, No.2.

Sekaran, U., and Bougie, R. (2016): Research Methods for Business- A skill Building Approach, $7^{\text {th }}$ Edition, John Wiley \& Sons, U.S.A.

Shafieian, G. (2014): Defining Talent Management Components, ISPACS: International Scientific Publication and Consulting Service, Mannheim- Germany.

Tepayakul, R., and Rinthaisong, I.(2016): Finding Components of Talent Mnangement System, Silpakorn University Journal of Social Sciences, Humanities, and Arts, Bangkok- Thailand, Vol.16, No.3..

Ulrich, D., \& Smallwood, N. (2012): What is talent?, Leader to Leader, Vol.63. 
Vaseghi, M. and Moayedi, Z. (2016): The Effect of Talent Management on Organizational Success, Journal of Accounting and Management, Scinzer Scientific Publications, ViennaAustria, Vol.2, No.3

Veal, A. (2006): Research Methods for Leisure and Tourism: A Practical Guide, 3rd ed., Pearson Education Limited, England. Vnouckova, L., Urbancova, H., and Smolova, H. (2016): Identification and Development of Key Talents through Competency Modeling in Agriculture Companies, ACTA UNIVERSITATIS AGRICULTURAE ET SILVICULTURAE MENDELIANAE BRUNENSIS, Czech Republic, Vol.64, No.4.

Ziadi, B, A. (2016): The Impact of Talent Management on Enhancing Competitiveness of Human Resources: A Comparative Study between Commercial Banks in the Public and Private Sector, Scientific Journal of Economics and Trade, Faculty of Commerce, Ain Shams University, Cairo- Egypt, Vol.3. 